\title{
A Multidisciplinary Approach for Historic Buildings Diagnosis: The Case Study of the Kaisariani Monastery
}

\author{
Ekaterini T. Delegou ${ }^{1, *, \dagger}$, Georgia Mourgi ${ }^{1, \dagger}{ }^{,}$Elisavet Tsilimantou ${ }^{1, \dagger}$, Charalabos Ioannidis ${ }^{2, \dagger}$ \\ and Antonia Moropoulou ${ }^{1,+}$ \\ 1 Laboratory of Materials Science \& Engineering, School of Chemical Engineering, National Technical \\ University of Athens, 9 Iroon Polytechniou str, 15773 Athens, Greece; georgiamrg@hotmail.com (G.M.); \\ eltsilim@mail.ntua.gr (E.T.); amoropul@central.ntua.gr (A.M.) \\ 2 Laboratory of Photogrammetry, School of Rural and Surveying Engineering, National Technical University \\ of Athens 9, Iroon Polytechniou str., 15773 Athens, Greece; cioannid@survey.ntua.gr \\ * Correspondence: edelegou@central.ntua.gr; Tel.: +30-210-772-3075 \\ + These authors contributed equally to this work.
}

Received: 22 February 2019; Accepted: 17 April 2019; Published: 20 April 2019

check for updates

\begin{abstract}
In this work, a multi-disciplinary approach regarding diagnostic study processes is presented, using as an example the Catholicon of Kaisariani Monastery in Attica, Greece. Kaisariani Monastery is considered one of the most important Byzantine architectural complexes in Greece. The Catholicon of Kaisariani Monastery was built during the middle Byzantine period, and has undergone many reconstructions during the centuries. It is a semi-complex, four-columned, cross-in-square church, with a cloisonné masonry. The suggested diagnostic processes included the creation of multidisciplinary thematic maps in Computer Aided Design (CAD) environment, which incorporated: (a) data of historical and architectural documentation; (b) data of geometric documentation; and (c) data of building materials characterization and decay diagnosis. The historical and general architectural data were acquired by thorough bibliographical/archival research. Geometric documentation data were acquired by three-dimensional (3D) laser scanner for the creation of the Catholicon section drawings, whereas image based photogrammetric techniques were utilized for the creation of a 3D textured model, from which orthoimages and architectural drawings of the Catholicon façades were developed. In parallel, characterization of building materials and identification of decay patterns took place after the onsite application of the nondestructive techniques of digital microscopy, infrared thermography and ground penetrating radar. These vast array kinds of data were elaborated and integrated into the architectural drawings, developing thematic maps that record and represent the current preservation state of the monument, a concerning major construction phases, the most important conservation intervention projects, building materials and decay. Furthermore, data quantification regarding the extent of building materials and decay at each monument's façade took place. Therefore, correlation and better understanding of the environmental impact on building materials according to façade orientation and historical data, e.g., construction phases, was accomplished. In conclusion, the presented processes are multidisciplinary tasks that require collaboration among architects, surveyor engineers and materials scientists/engineers. They are also prerequisites for the planning and application of compatible and efficient conservation/restoration interventions, for the ultimate goal of the sustainable protection of a monument.
\end{abstract}

Keywords: multi-disciplinary approach; diagnostic study; geometric documentation; non-destructive techniques; thematic maps; sustainable protection; church; cultural heritage 


\section{Introduction}

The conservation and preservation of important cultural heritage assets has become a concern of the interdisciplinary scientific community. Current studies illustrate that, through a multidisciplinary approach, in the field of cultural heritage, a cohesive documentation incorporating information regarding not only the architectural and geometric documentation but also historical and archaeological research, building material and decay documentation and structural research provide crucial information regarding the preservation state of a monument, possible conservation interventions and rehabilitation. Since the resources for constructing new buildings in Europe has declined, the scientific and construction community has gained growing interest in restoring and rehabilitating old buildings and monuments [1,2]. To achieve sustainable protection and restoration of such assets, a multidisciplinary approach is a prerequisite. In addition, the characterization of building materials and decay is of utmost importance, especially in terms of intervention conservation practices. For the protection of a monument, in most cases, it is forbidden to take samples [1,3]. Therefore, the scientific community turns to non-invasive and no-contact practices to acquire the necessary information. In the geometric documentation and architectural documentation field, this practice is performed with the use of laser scanning and image based techniques, keeping the monument intact. For the building materials characterization, non-destructive techniques (NDT) are utilized for the determination of the pathology of a monument. These vast amounts of data can contribute to the protection of cultural heritage assets and also for the decision making on conservation approaches [2-5].

Over the last decade, there is an immerse use of digital documentation processes, especially for the creation of textured three-dimensional (3D) models [6-8]. The 3D architectural surveys nowadays utilize techniques provided by surveying and photogrammetric scientific field and use two methodologies: close-range based modeling and image-based modeling [6]. The first one includes the use of laser scanning techniques to obtain a 3D dense point cloud in the same reference system with below sub-centimeter accuracy [8,9]. The other survey includes computer vision algorithms combined with photogrammetric procedures and provides a 3D model with radiometric information importing the texture in the model $[10,11]$. Currently, the scientific community tends to utilize both surveys, especially in cultural heritage documentation where the building materials play a pivotal role in the documentation process. In this case, both survey methods are elaborated and integrated, providing a textured 3D model [12-15].

For the protection of a cultural heritage asset, the classification and representation of a monuments' pathology aims to control the decay progress and to improve planning of conservation interventions [1]. Within the framework of cultural heritage assets protection, practical needs emerge regarding the integrated study - management and the knowledge deriving from incompatible interventions towards an interdisciplinary integrated approach. Especially in the case of ancient masonry structures, additional inspection of the monument is necessary and certain factors are important to be obtained.

Nowadays, the research community is beginning to investigate multidisciplinary methods of data acquisition and further elaboration of information in a multispectral, multilateral and multidisciplinary manner. Moreover, the academic community adopts such approaches, especially for the investigation of assets construction phases, deformations and restoration practices, for their visualization and projection in multiple digital platforms. The tendency is to create 3D models (via Geographic Information System (GIS) or Building Information Model (BIM) software) [16-18] incorporating information of the abovementioned disciplines as well as other depending on the project's scope (documentation, visualization, dissemination, restoration etc.).

This study aimed to investigate a multidisciplinary approach, starting from the documentation of multidisciplinary data, which includes their architectural, historical, geometric and building material documentation data, and studying their interrelation for historic building structures, that contributes to the structure's current state assessment. Using documentation information system, and in particular two-dimensional (2D) maps that derive from the 3D documentation process, in accordance with the use and results of NDT and evaluation (E) techniques, the interdisciplinary diagnosis of decay 
patterns and their causes can be supported $[19,20]$. Additionally, this approach and the developed thematic maps can facilitate, as the first and crucial step, the planning and application of compatible conservation interventions.

The selected monument for the implementation of this process is the Kaisariani Monastery church. The whole complex consists of Byzantine baths, kitchen, and hearth, reflectory, cells, Benizelos tower and the Catholicon [21]. The long prosperity of the Kaisariani Monastery is owed to its privileges and fertile surrounding land property. A significant library was located also in the monastery. The devastation of the monastery after the 18th century had a dramatic impact over the church [22]. The monastery, due to its history, has undergone many construction phases throughout the centuries with three main phases prevailing.

\section{Materials and Methods}

The technological advances in the field of geometric documentation offer many different combinations for the 3D geometric documentation of monuments, depending on its size, the level of complexity, the desired and required accuracy of the developed outputs and the equipment. In this study, a combination of different methods was the ideal solution for the geometric and architectural documentation to achieve the intended results. In this section, the materials and methods for the multidisciplinary documentation are presented.

\subsection{Geometric Documentation}

\subsubsection{Photo-Based Data Acquisition}

A 3D textured model of the Catholicon was realized with the integration of Structure from Motion (SfM) and Multi-View Stereo (MVS) with classic photogrammetry procedures. The 3D textured model of the exterior of the monument provides the necessary geometric information of the façades and the surface details of the structure as well as the radiometric information necessary for the development of the building materials maps.

For the photo-based data acquisition, a Canon EOS 1Ds Mark III digital camera, manufactured in Japan with a CMOS sensor ( $36 \mathrm{~mm} \times 24 \mathrm{~mm}$ ), with a fixed 24-mm lens and a NIKON D70 manufactured in Bangkok, Thailand with a 6.1-megapixel sensor $(23.7 \mathrm{~mm} \times 15.6 \mathrm{~mm})$, with a fixed $18-\mathrm{mm}$ lens, both provided by the Laboratory of Photogrammetry, of the School of Rural and Surveying Engineering, National Technical University of Athens, were used. These cameras were used for the terrestrial photogrammetry and photorealistic texture mapping for the quality of the produced images.

A specific number of digital images was taken according to the part of the monument that should be documented and the difficulties that arose in each case. In addition, tree trunks, nearly in contact with the west façade, added difficulties in the data gathering process. Digital images were taken from different angles and distances. In the case of the north façade, the documentation was very difficult, especially in the higher part because of the proximity of an exterior wall of the Monastery; therefore, the images were taken at a close distance (in many cases, less than $1.5 \mathrm{~m}$ ). In total, approximately 150 images for each façade were taken from various distances and multiple angles, covering the exterior façades of the Catholicon. The development of the 3D point cloud and the textured model deriving from the photo-based methods was accomplished with the Photoscan Agisoft $₫$ software, by Agisoft LLC, St Petersburg, Russia. Furthermore, in the developed model of the Catholicon, all the exterior walls incorporating texture, surface variation, material differentiation and alterations were obtained.

\subsubsection{Laser Scanning Data Acquisition}

The 3D model of the Catholicon (both interior and exterior as a model), obtained by a Leica Scan Station 2 laser scanner was provided by the Laboratory of Photogrammetry, with an average spatial resolution of $\pm 5-6 \mathrm{~mm}$. The 3D point cloud consists of all the referenced point of the surveyed area creating a Dense Digital Surface Model (DDSM). This model facilitates as a blueprint for further 
elaboration of the architectural documentation of the monument. A proper selection of points was made to formulate the various plans and sections of the structure. The distance between the points is less than $1 \mathrm{~cm}$ due to its density. Therefore, it was possible to obtain specific details that otherwise would be difficult to acquire in terms of time.

\subsection{Architectural and Historical Documentation}

Bibliographical research was carried out to collect all the available information regarding the architectural analysis of the monument (Byzantine church) since it was documented in 1952 [15]. In addition, a research on previous interventions on the church was accomplished. All the interrelated information regarding the documentation and the investigation of the church' current state of preservation consists of various data. Starting from the historical documentation, a complete and in-depth understanding of the structure and history through a thorough bibliographical research, including older photographs, plans and draft sketches the historical documentation, was accomplished. Along with this documentation process and in-depth research, additional research on past architectural documentation studies was obtained, regarding existing deformations and anomalies, analysis of the deterioration state and possible past incompatible interventions, architectural drawings, plans and sections, which are necessary for the construction assessment, possible damages and alterations leading to the static integrity assessment of the monument [23]. For the architectural documentation process, the 3D model was elaborated. The 3D point cloud was imported in 3DCAD Map 2015 information system without losing its resolution or georeference. The section levels were determined. For the creation of the sections and the segmentation of the 3D point cloud based on the predefined sections, Geomagic Studioßsoftware by 3D Systems, US, was utilized.

\subsection{Building Materials Characterization}

For the documentation and analysis of the Catholicon's masonry, non-invasive, and non-destructive techniques were performed. Digital Microscopy (DM), Infrared Thermography (IRT) and Ground Penetrating Radar (GPR) were applied in selected areas in the exterior of the Church after in situ inspection. In addition, Schmidt hammer test was applied for the evaluation of the building material's compressive strength [24]. Digital microscopy was utilized for acquiring in-situ magnified visual spectrum images of a selected surface and provided an initial building material characterization along with an assessment of the decay. It also contributed to the determination of different construction phases' building materials or even non-documented restoration works. In this survey, a Digital microscopy i-scope-Moritex was applied at several magnifications $(\times 30, \times 50$ and $\times 120)$. The Ground Penetrating Radar uses radar pulses to examine the sub-surface area of a structure. Voids and inclusions can be documented and the state of preservation of the structural system can be examined. In addition, with GPR measurements, the morphological and geometrical characteristics can be revealed in a layered and brick masonry structure. In addition, past interventions can be evaluated. In this survey, the ground penetrating radar system used was a MALÅ Geoscience ProEx system by Guideline Geo AB, Sundbyberg, Sweden, with $1.6 \mathrm{GHz}$ and $2.3 \mathrm{GHz}$ antennae. For data acquisition, the MALA Geoscience Groundvision 2 software by Guideline Geo AB, Sundbyberg, Sweden was used. The MALÅ Geoscience RadExplorer v.1.41 software was used for data processing. The Infrared thermography detects the radiation in the infrared range emitted by the building materials and the structures surface. Variation in construction phases and past restoration works can be detected. It can detect areas with humidity issues and moisture transfer phenomena on monumental scale. The infrared camera used in the survey was a FLIR Systems Therma Cam B200, with a detector of focal plane array microbolometer in the spectral range of $7.5-12 \mu \mathrm{m}$, with thermal sensitivity of $0.08{ }^{\circ} \mathrm{C}$. During the survey, the environmental conditions were measured [24]. 


\section{Results}

\subsection{Geometric Documentation Data}

The next step was the elaboration of the orthoimages of each façade with a pixel (groudel) size of $2 \mathrm{~mm}$. Initially, each façade was elaborated as a different project, using masks in the areas of occlusions (Figure 1). After the elaboration of the data for all the façades, a 3D model of the Catholicon was produced. For the georeference of the façades in a common reference system, characteristic points of the 3D model already obtained by a laser scanner were depicted. The accuracy obtained for each façade after the elaboration and correction of the point cloud was approximately $1-1.7 \mathrm{~cm}$, within acceptable limits for the further development of the thematic maps.

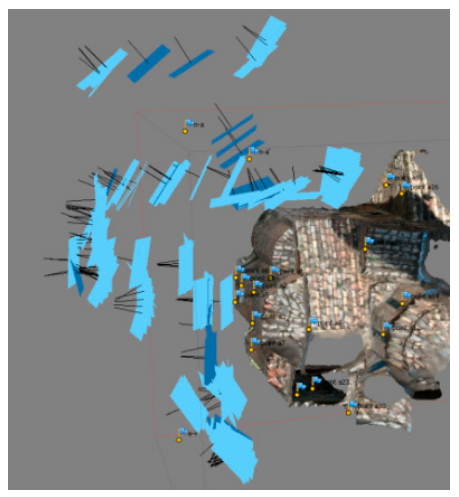

(a)

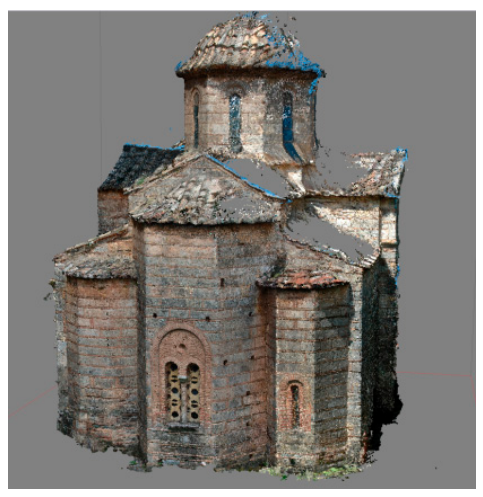

(b)

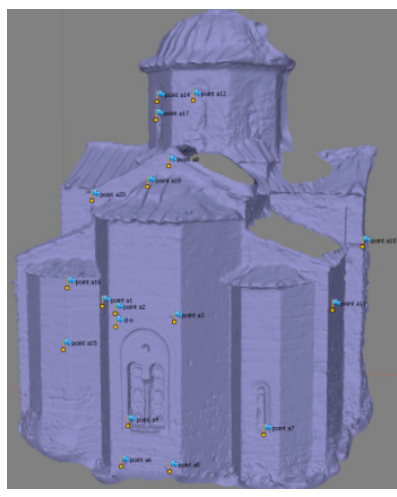

(c)

Figure 1. (a) Camera positions during the process of the alignment; (b) dense point cloud of the east façade; and (c) 3D mesh of the east façade.

For the elaboration of the orthoimages of each façade, selected images were used to assure quality texture. To proceed with the multidisciplinary process, four orthoimages were created, one for each façade of the Catholicon (Figure 2). These orthoimages acted as blueprints for further elaboration of thematic maps incorporating not only qualitative information but also quantitative data.

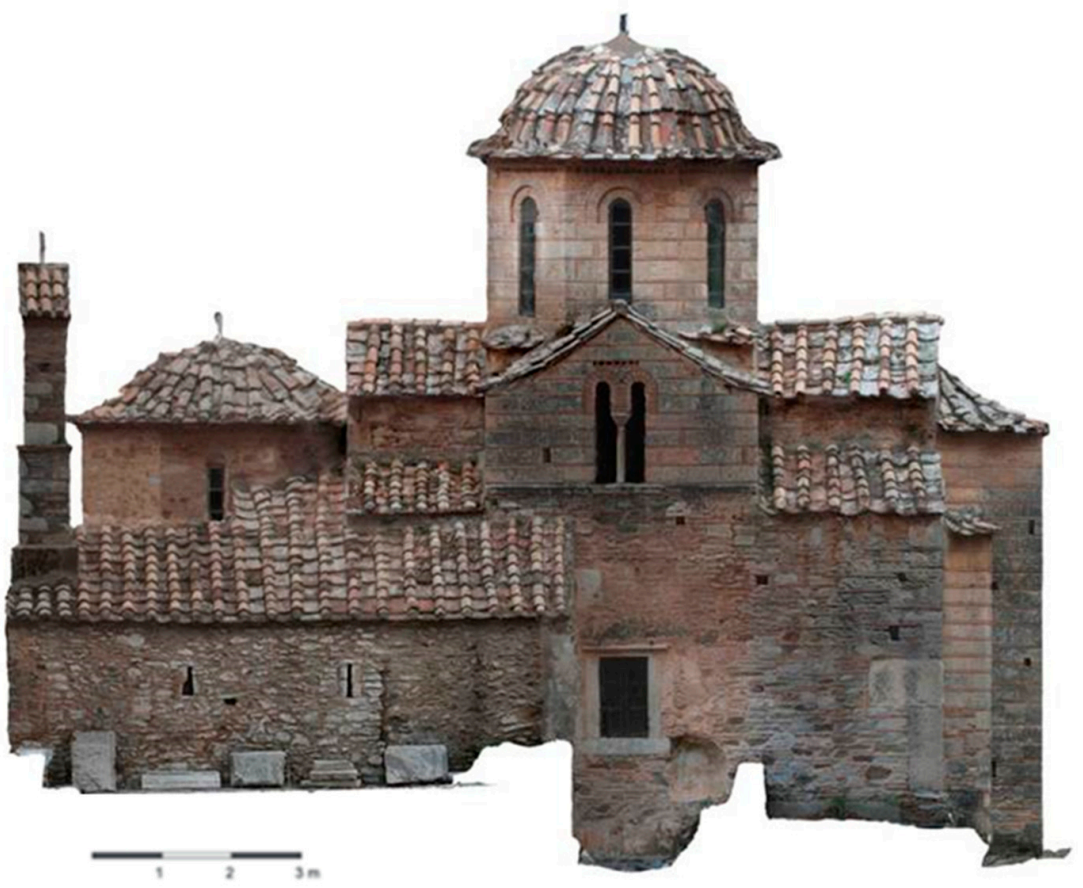

Figure 2. Orthoimage of the south façade of the Catholicon. 
For the development of 2D drawings (plans and sections), several methods were used. The required resolution was $\pm 1.5 \mathrm{~cm}$. Apart from the architectural documentation of the structure, the survey aimed to detect various deformations and alterations in comparison with the initial state of the structure. Initially, the section levels were determined (Figure 3a,b); two sections that constitute the main symmetry axes of the monument and one additional section level of the Narthex, which crosses the highest level of the temples dome. In addition, a horizontal section was set at $+2.10 \mathrm{~m}$ elevation to cross the majority of the temple's openings.

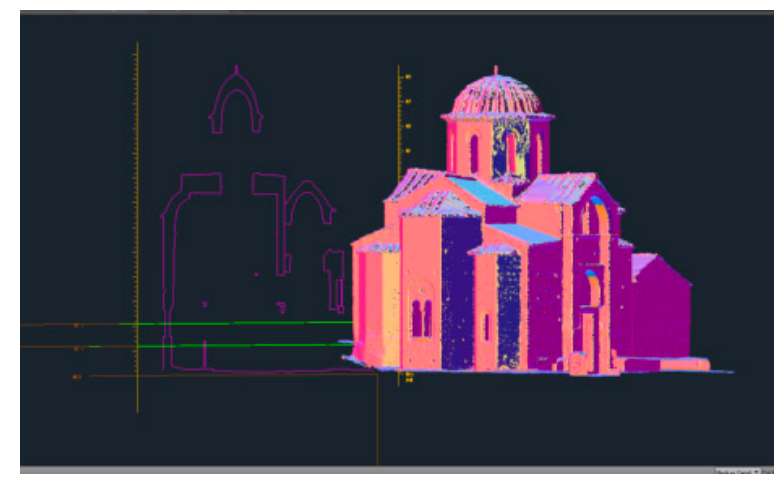

(a)

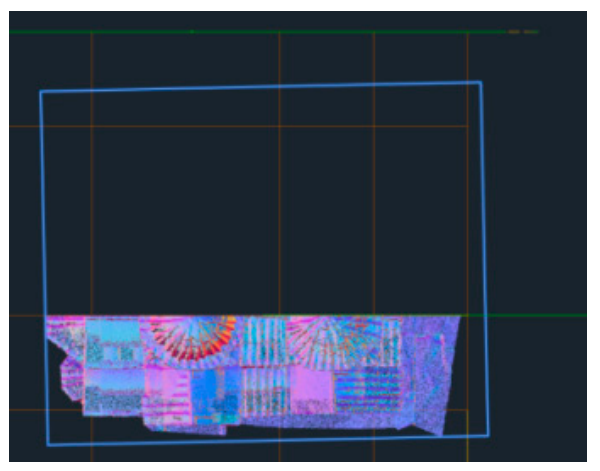

(b)

Figure 3. (a) 3D point cloud of the Catholicon as imported in the 3DCAD environment; and (b) cropped point cloud from the predefined section in the Geomagic Studio environment.

\subsection{Historical Documentation Data}

The Catholicon of Kaisariani Monastery is the conventual church of a prosperous monastery complex, constructed in the 12th or late 11th century; the exact date of construction is not known. It was dedicated to the Presentation of the Virgin to the Temple and is located in mount Hymettus, at the outskirts of Athens. The Kaisariani Catholicon Main Church is mentioned or analyzed by various researchers of Byzantine architecture, as it represents a typical sample of the mid Byzantine Greek school, following the four columned cross in square type (Figure 4a,b) [22]. Morphologically, it is characterized as "strict" [25], as it consists of clear geometrical volumes and premium construction quality. Its singularity concerns that the internal structure manages to be externalized in a simple way and without exceeding the human scale. According to the era formula, the building construction is mainly brick and stone cloisonné masonry style, which is better performed on the eastern façade, the dome and the cross arms, where porous ashlar is used. The rest masonry is built with semi- cloisonné style and limited parts of rubble masonry.

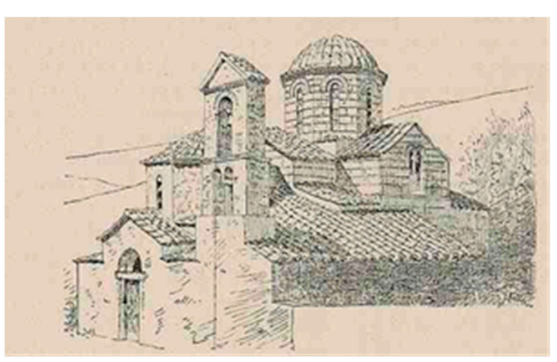

(a)

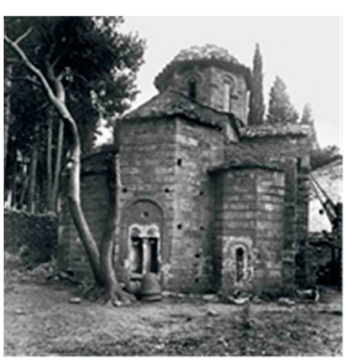

(b)

Figure 4. (a) Documentation of the southwest of the Catholicon by Dell in 1889 (Adopted from [22]); and (b) Photographic documentation of the east façade of the Catholicon in 1888-1890 (Adopted from [22]). 
The first construction phase includes the original building that was a complex cross-in-square four-column domed church, constructed during middle Byzantine period (second half of the 11th century or early 12th century). In the 17th century, the domed Narthex was added during the Turkish domination and the barrel-vaulted chapel dedicated to Aghios Antonios, located in the southwest of the Catholicon, was the third addition to the church, probably in the same century (Figure 4a). Therefore, the Kaisariani Church consists of three main construction phases and a 4th with the construction of the tower bell, added probably during 18th to 19th century. Therefore, the construction phases are the Main Church (11th-12th c.), the Narthex (17th c.), the St. Antonios chapel (17th-18th c.) and the tower bell (18th-19th c.) (Figure 5) [26].

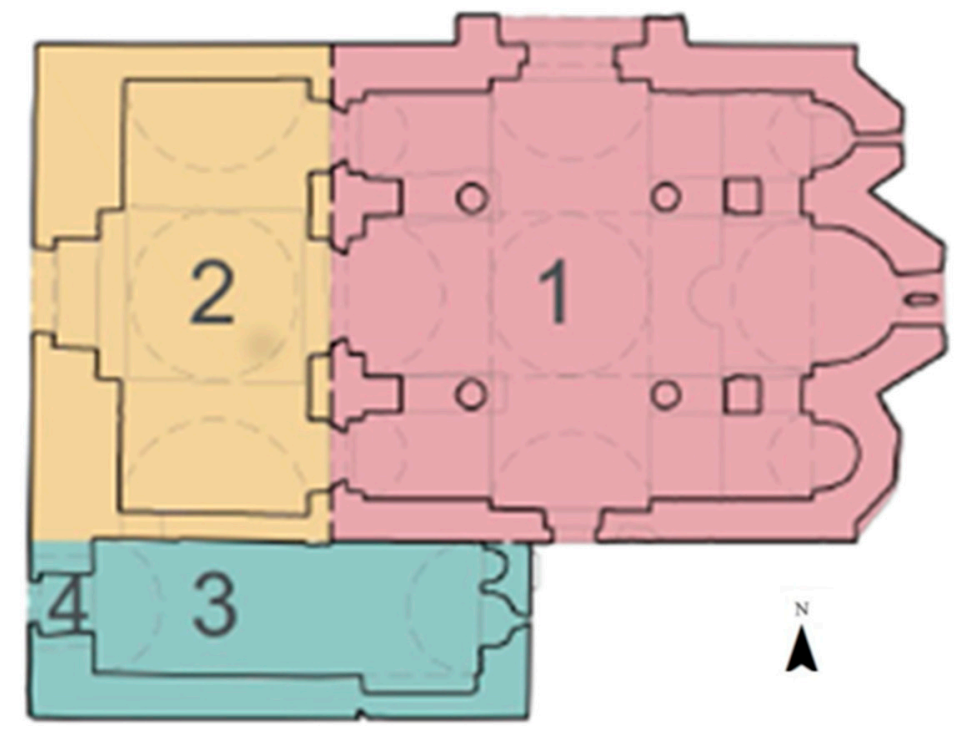

Figure 5. Ground Plan of the Kaisariani Church with three construction phases; Main Church (1st C. Ph.); Narthex (2nd C. Ph.); St. Antony Chapel (3rd C. Ph.-4th C. Ph.). Plan of the Catholicon.

In the lower masonry layers, many big-sized stones are built in second use. A horizontal cornice divides the south and north façade on the same level. The north cross arm is highlighted with a perfectly built protruding arch based on two pilasters, which encloses a double-light window. Other exceptional ornamental elements are the dentil course of the octagonal dome and the brick frame of the eastern grouped type double light window where a glazed bowl was built in (Figure 4b). Many spolia coming from Roman or later buildings were built in the structure and some of them bear Byzantine relief decoration [26]. The four ancient marble columns of the interior of the Catholicon bearing Ionian capitals carry the load of the octagonal dome, connected with wooden tie beams above the capitals level. The domed Narthex of the 17th century located in the west belongs to latter construction phase. It was built with rubble masonry and the door was built with spolia. South of the Narthex and part of the Catholicon, a vaulted chapel was added, also built with rumble masonry. A mural painting of the 14th century inside the chapel on the outside surface of the Main Church's south wall raises the question of the existence of an earlier building in the same location. The last construction phase is the bell tower, an addition of the later centuries.

\subsection{Architectural Documentation Data}

The monument comprises a mid-Byzantine cross-in-square four-column domed church. It can be observed that, in such churches, there is a connection between the typology, the morphology and the structure. The structure follows the basic rules while pursuit of symmetry is evident. From the developed products of the sections and plans, various drawings were elaborated. The exterior dimensions of the Main Church are $9.47 \mathrm{~m} \times 8.12 \mathrm{~m}$ and the dimensions of the basic orthogonal plan are $6.65 \mathrm{~m} \times 5.88 \mathrm{~m}$. Towards the west, the Narthex expands $5.43 \mathrm{~m}$ and, towards the south, the chapel 
expands $2.92 \mathrm{~m}$. The thickness dimensions of the wall structure are $70 \mathrm{~cm}$ on the south façade, $75 \mathrm{~cm}$ on the north façade, $80 \mathrm{~cm}$ in the recesses towards north and $60 \mathrm{~cm}$ on the west façade. Drawings of the plans, cross sections and long sections were developed (Figures 6 and 7).

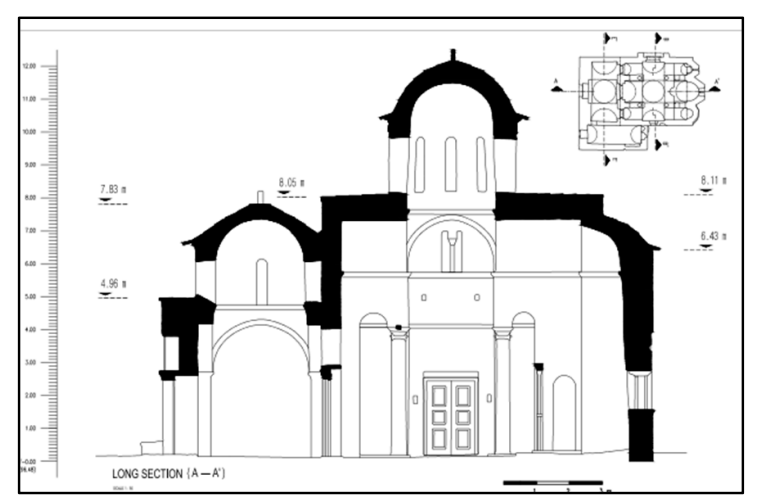

(a)

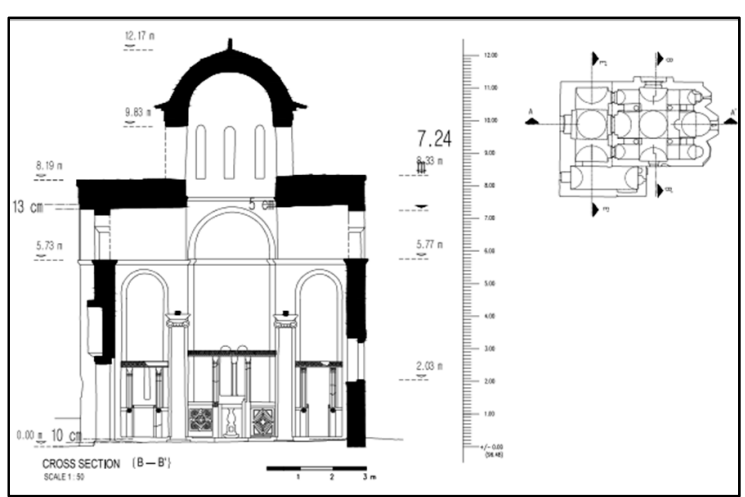

(b)

Figure 6. (a) Long Section drawing of the Main Church; and (b) Cross Section drawing of the Main Church.

The architectural documentation drawings (deriving from the geometric documentation), provided information regarding the structure's state of preservation. Deviations from the vertical or alteration in the structures surface were observed and validated. In the Main Church, no deviation from the vertical in the long section was observed (Figure 6a), whereas a $5 \mathrm{~cm}$ recess of the arches ground level was observed, due to dome's vertical loads (Figure 6b). In the case of St. Antonios Chapel, a $10 \mathrm{~cm}$ deviation from vertical was documented (Figure 7a).

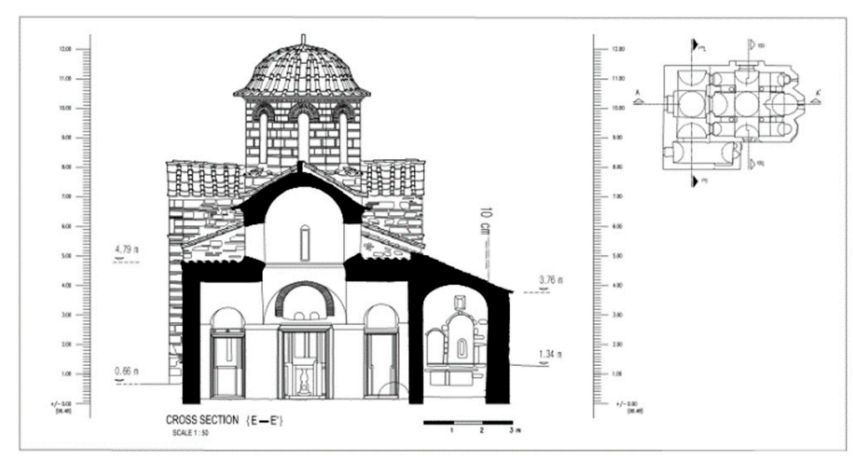

(a)

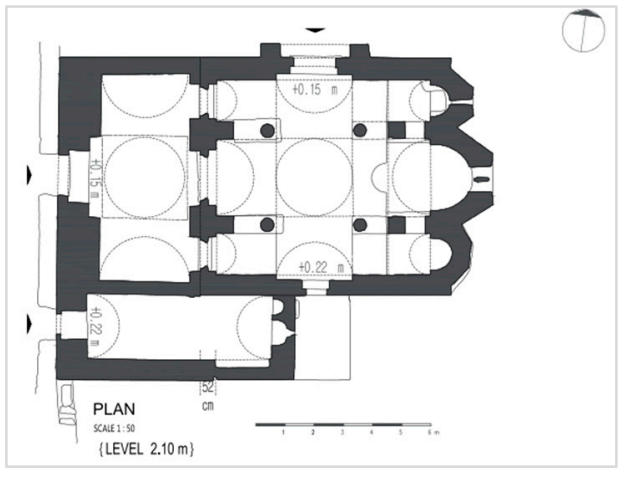

(b)

Figure 7. (a) Cross Section drawing of St. Antonios Chapel; and (b) plan of the Catholicon.

Moreover, the developed orthoimages from the geometric documentation process were digitized for each façade, contributing to the multidisciplinary process, as presented in this work. Every element was classified in terms of building material, decay, architectural and artistic details (Figure 8a,b). During the process of mapping of the classified data, various layers of information were created, formulating a database. Each layer was created once and was attributed to each façade to avoid duplications. 


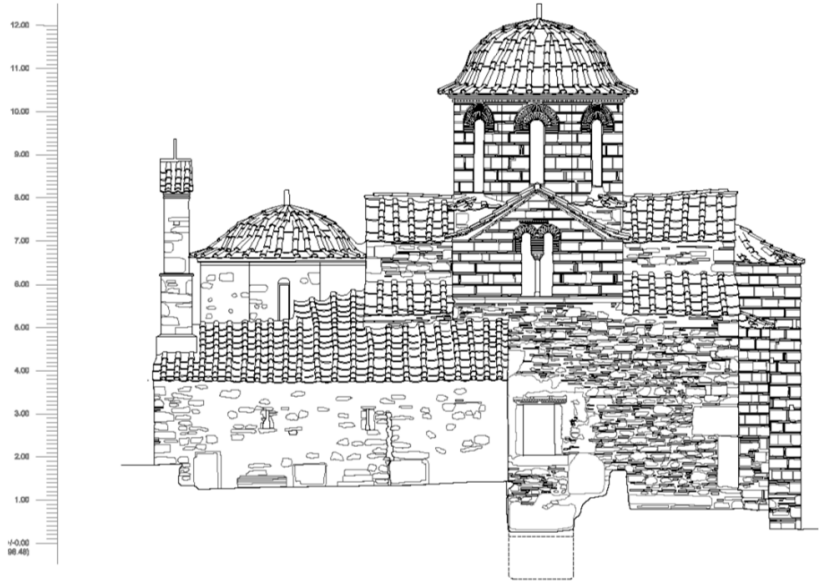

(a)

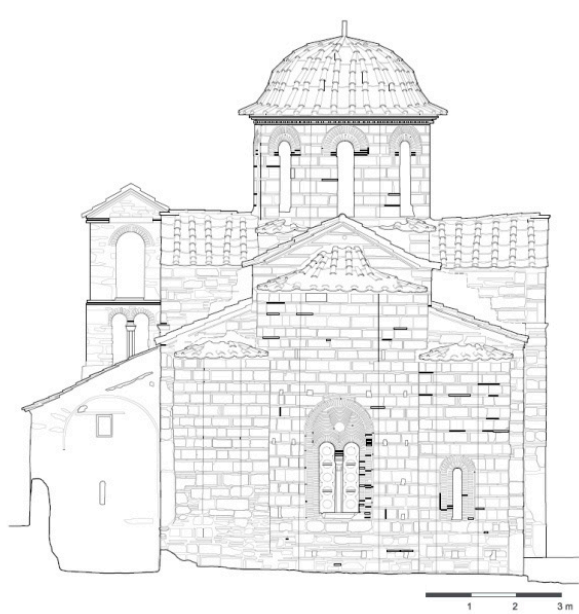

(b)

Figure 8. (a) Architectural drawing of the south façade of the Catholicon; and (b) architectural drawing of the east façade of the Catholicon.

\subsection{Building Materials Investigation}

During the past years, many conservation treatments have been carried out in the monastery complex, including the church, which were not fully documented. The only documented conservation intervention work was performed during two important reconstruction projects, one in the early and the other one in the middle 20th century. The interventions were mostly applied on buildings that were surrounding the Catholicon, such as the bath installations and the complex containing the kitchen and the refectory $[27,28]$. Many conservation projects were realized within the monastery area, by the 1950s, such as the excavation of the east side of the church and other limited repair works. During 1950s, an extended conservation project was accomplished, where part of the eastern window frame and the north gate of the Catholicon were reconstructed. In addition, a concrete shell was constructed in the exterior of the foundation of the eastern façade. In addition, another conservation project was carried out by the Ministry of Culture from 2002 to 2008 to restore the damages raised from the 1981 and 1999 earthquakes. Moreover, the chapel of Aghios Antonios was repointed in 2011, using a lime-pozzolan mortar [24].

The NDT results were combined to extract information regarding the building materials, the decay patterns, the monument's state of preservation as well as the detection of past restoration materials and implemented interventions (Figures 9 and 10). From these results, along with in situ visual inspection, the identification and classification of material and decay types was accomplished. This process enabled also the documentation and assessment of non-documented interventions alongside with the material and decay analysis.

Various materials and construction techniques are present due to the different construction phases. The following building materials were evident according to NDT diagnostic study and were evaluated and validated in lab after sampling investigation. Ministry of Culture gave permission only for the study of the exterior façades of the monument and documentation of the interior as well as other parts such as the roof could not be realized. In addition, there were high sampling restrictions due to the monument's importance and only a few mortar samples were collected for lab investigation [24]. Therefore, it was not possible to obtain pictures of the stratigraphy details of the structure, since the Ministry of Culture did not allow core drilling and the information acquired regarding the structure of the monument were obtained by NDT deployment. Information concerning the structure of the various phases of the Catholicon is illustrated in Figure 9a, which shows information about the first construction phase of the Catholicon, the masonry of which is a three-leaf one, as GPR measurements displayed [24]. 


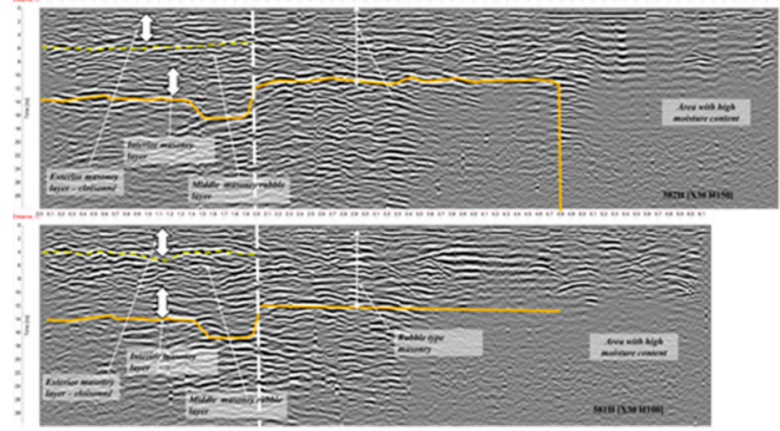

(a)

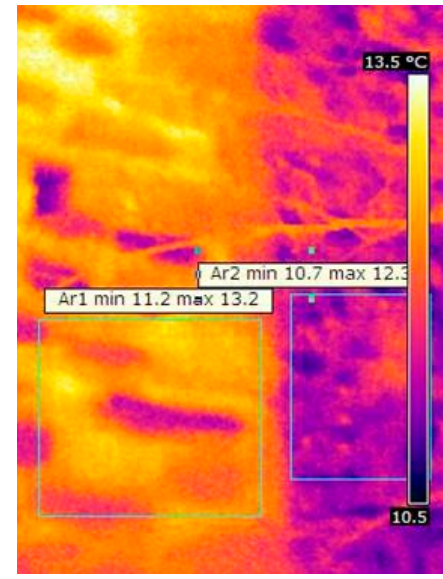

(b)

Figure 9. (a) Characteristic Results from the GPR measurements; and (b) IRT image of the north façade (Adopted from [24]).
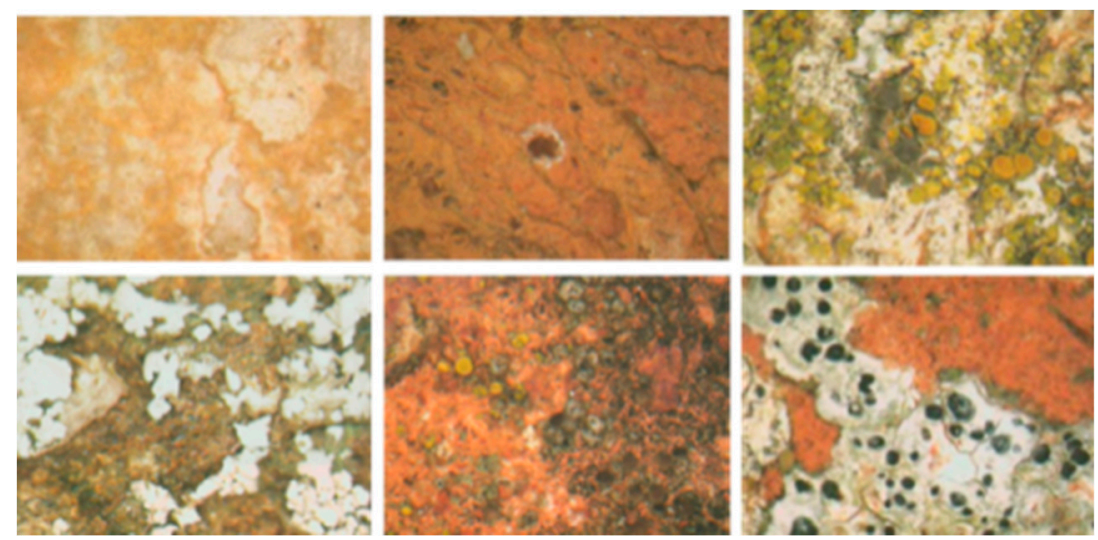

Figure 10. DM images of decay (various types of lichens and black bio decay) (Adopted from [24]).

The documented stones were: fossiliferous limestone, beige off-white porous stone, grey porous stone; compact limestone, limestone of red hue (reddish stone), compact stone of green hue (greenish stone) and schist. The bricks were classified as: bricks of red hue (reddish bricks) and bricks of yellow hue (yellowish bricks). The structural mortars of the church were typical lime mortars reinforced by straws.

Specific areas of the north, south and most of the east façade of the Main Church were built with ashlar porous stone and compact bricks according to the typical "plinthopericleiston" system of mid-Byzantine masonry (Figure 9a). Rumble stone covered the rest of the north and south façade of the Main Church and the walls of the Narthex and Chapel (Figure 9b). More specifically, three different types of porous stone were encountered in the Main Church. A fossiliferous porous stone constitutes the main building material along with compact bricks, various types of limestones, and two different types of porous stones, schist and marble. Apart from two main building mortars, five additional types of mortars were detected on the north façade. Moreover, a restoration mortar is located around the door opening with four additional layers of repair mortars mapped on the wall of the Narthex. Perhaps two of them are cement, indicative after visual inspection $[29,30]$.

The Main Church (first construction phase) is a typical Byzantine three-leaf masonry, whereas Narthex is a rubble masonry. The porous stone of the east façade is a fossiliferous stone. The original mortar of the east façade, although attributed to the first construction phase, and therefore subjected to environmental factors for a much longer period compared to the subsequent phase materials, is in a good preservation state [24]. 
In addition, a plethora of decay patterns are evident according to NDT diagnostic study (Figure 10). They can be analyzed as extended bio decay, consisting of black fungi (black bio decay), crustose epilithic lichens, foliose epilithic lichens, mosses, plants, brownish depositions, cracks, material loss/scaling (including mortar depletion), rising damp and penetrating damp, and incompatible conservation interventions, especially in the Narthex.

\section{Discussion}

\subsection{The Elaboration of the Historical Documentation Towards the Development of Thematic Maps of Construction Phases}

As presented in the monument's construction phases and the restoration interventions (Figure 11), the Main Church retains the authentic building materials, apart from a specific area located around the door of the northern façade and the two windows of the eastern façade, where a non-documented restoration intervention took place during the 1950s [24]. Additionally, past and most recent restoration interventions are evident and documented on the west and north exterior walls of the Narthex and the west façade of the chapel. The eastern façade has undergone fewer interventions than the others, while, on the west façade, the restoration interventions cover the entire masonry and there is evidence of repair mortar as well (Figure 11a).

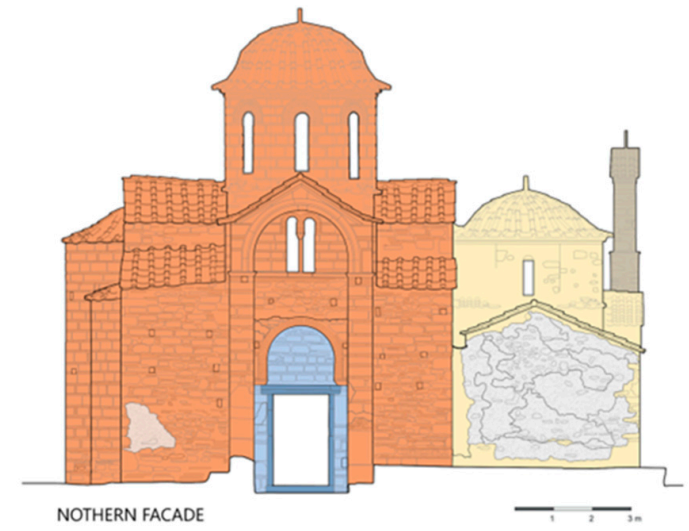

(a)

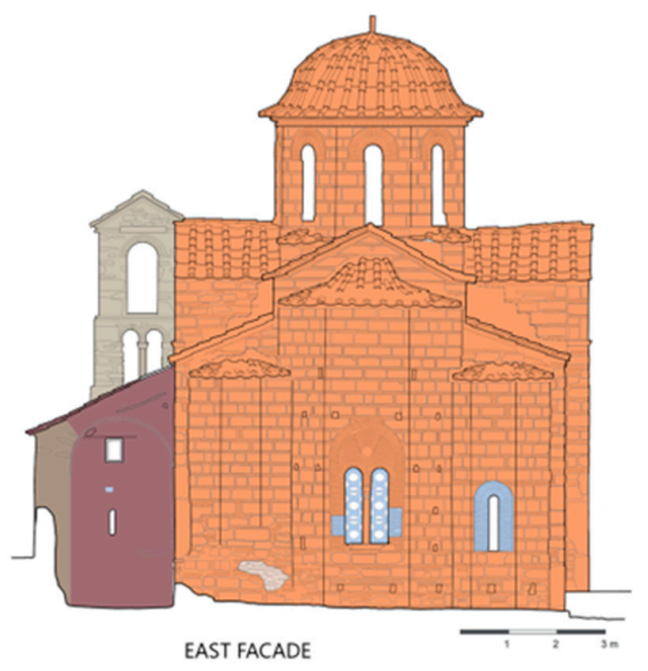

(c)

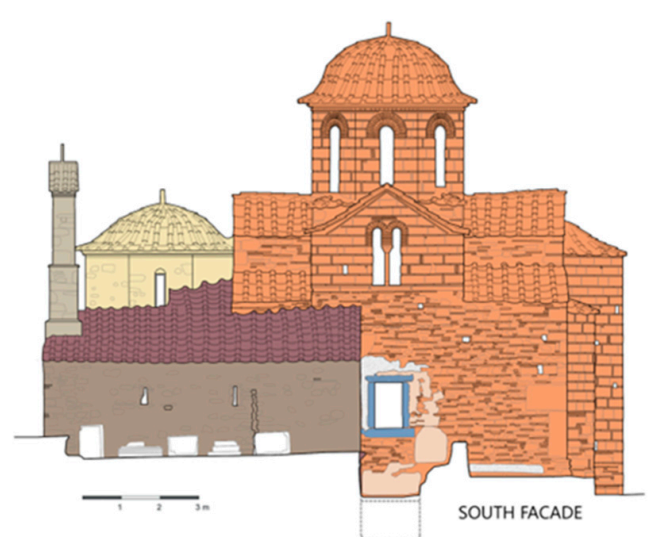

(b)

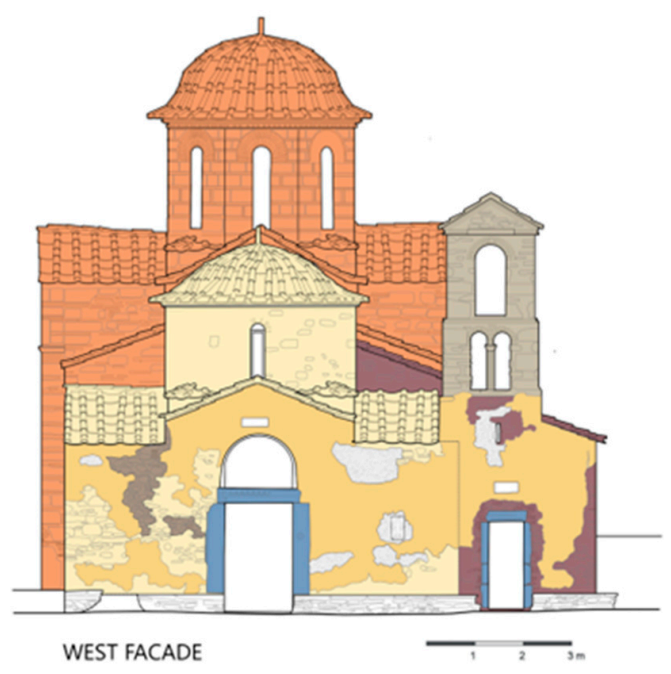

(d)

Figure 11. Cont. 


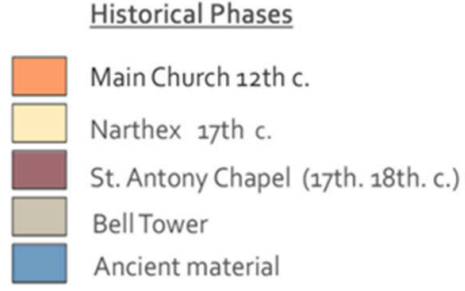

(e)

\section{Interventions}

Facade rendering (end of 19th. c.)

Restoration Intevantion (1950)

Latest intervantion(2011)

Various repair intervantions

Figure 11. (a) Construction phases thematic map-north façade; (b) construction phases thematic map—south façade; (c) construction phases thematic map-east façade; (d) construction phases thematic map—west façade; (e) historical phases; and (f) interventions.

\subsection{Elaboration of NDTs for the Development of Thematic Maps}

Since its early construction, the Catholicon has undergone many and various construction interventions, some of which were analytically documented and could be found in the archives of the Local Ephorate of Antiquities. However, the use of NDT is currently utilized by the scientific community to evaluate and assess the compatibility of past conservation-intervention works. The NDT techniques that were applied for the assessment of the church's current state of preservation indicated surface morphology variations, texture differences and variable surface composition. These variations led to the classification of the building materials and decay data. In addition, areas of increased or reduced emissions were revealed, providing information of structural variation of the masonry, information that was strengthened by the on-site visual inspection of the construction phases and the bibliographic research.

Recording, classification, distribution and representation of building materials on a surface scale, on the monument's façade, was applied for the exterior of the Catholicon, based on visual inspection and NDT evaluation. The combination of the NDTs resulted in the validation of the building materials and decay pattern classification and therefore was integrated within the CAD information system. In Figure 12, the classification of the fossiliferous porous stone with $51 \mathrm{~cm}$ length and $21 \mathrm{~cm}$ width is one of the building materials type encountered in this typical "plinthopericleiston" system of the Catholicon masonry, which includes one layer of stone, one layer of filling mortar and one layer of brick, enclosing each stone. The width of the brick as well as the width of the filing mortar is the same, approximately $2 \mathrm{~cm}$.

On the north façade, integration between DM and IRT results in the validation of different type of construction between the Narthex and the Main Church, since the Narthex is an area of high moisture and, additionally, the susceptibility to bio decay and lichens of the north façade illustrated by DM results is evident (Figure 13).

On the east façade, integration of visual inspection and DM images, reveal that $8 \%$ of the historical bricks present scaling and material loss just above the rising damp zone, probably due to the presence of the concrete ground work base (Figure 14).

\subsection{Thematic Maps of Building Material and Decay}

Thematic maps of building materials and decay of all the façades were developed. The north and the east façade were chosen since they represent two different states of preservation. In addition, the variation of the construction phases, demonstrated in these façades can contribute to the assessment of the state of preservation, the incompatibility of past restoration works is revealed via the decay thematic map.

In the thematic map of building materials on the north façade of the Catholicon, the variation of materials is evident (Figure 15). The past restoration works performed in the Narthex of the monument is almost as a patchwork having lost almost completely the structural layer underneath. In the decay thematic map (Figure 16), the mortar microfractures (brown color) can easily provide information of 
the incompatibility with other restoration works. Moreover, there is a significant amount of black bio decay (purple color) that covers almost the entire structure.

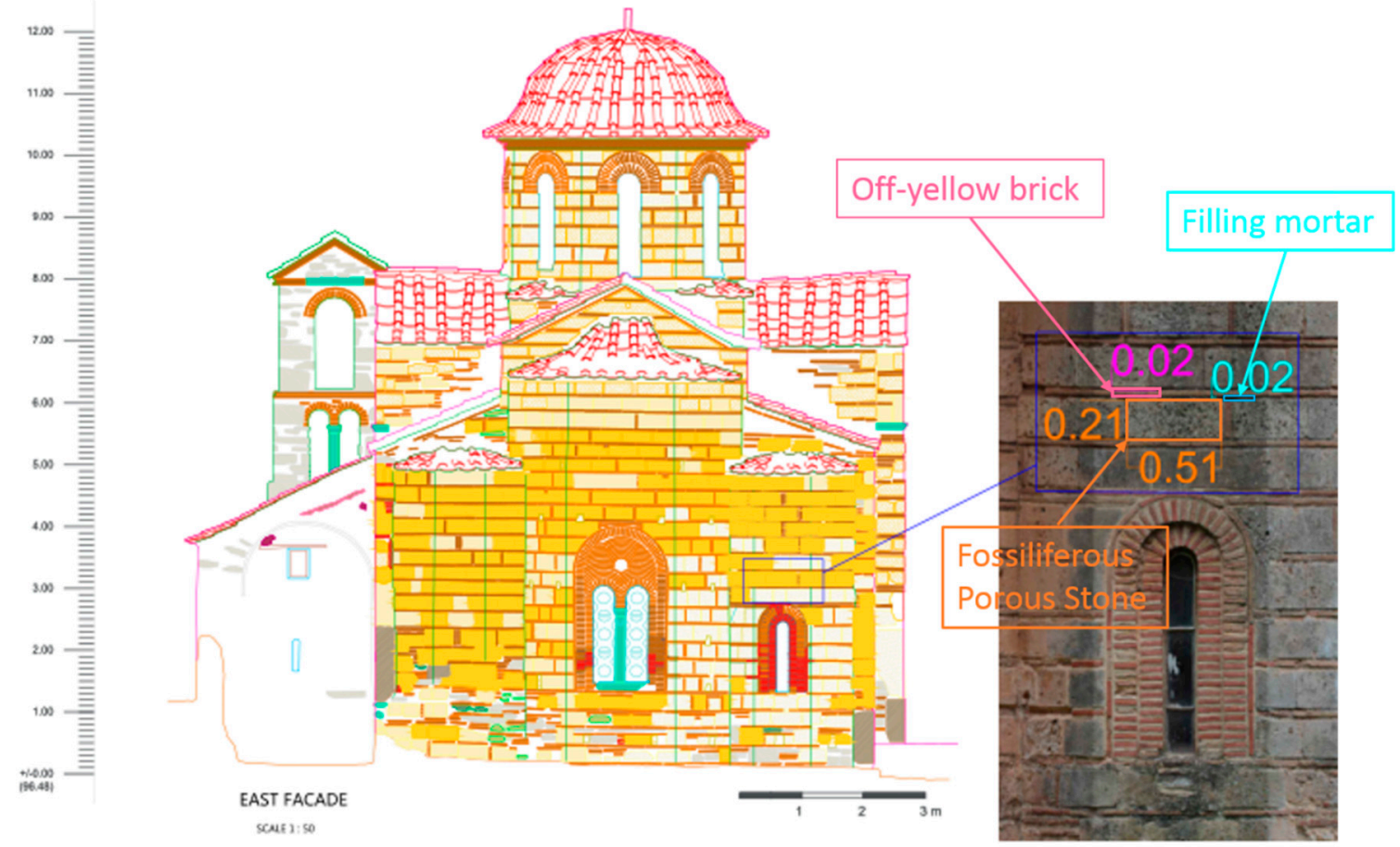

Figure 12. Classification and validation of building materials integrating NDT results with geometric documentation.

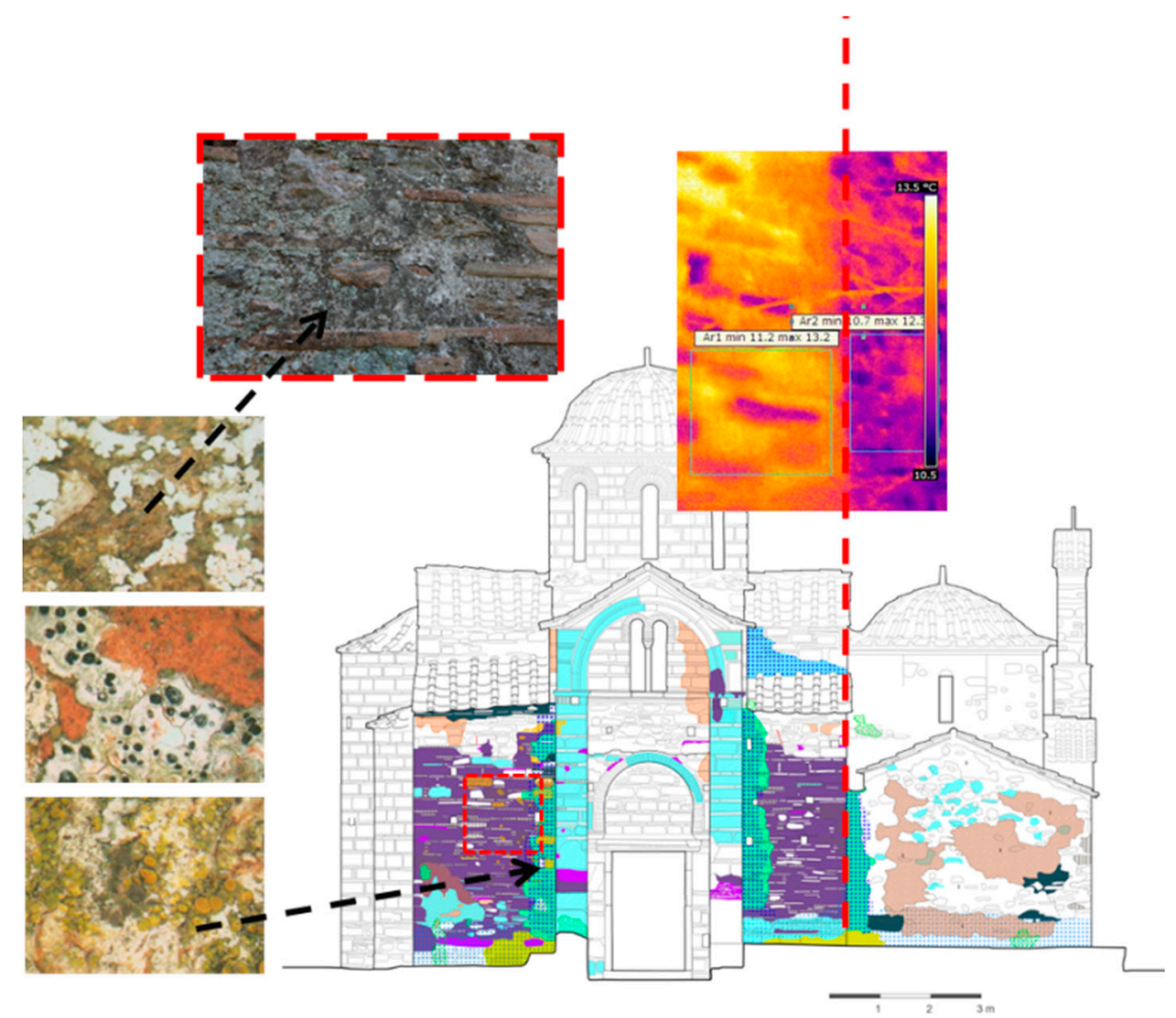

Figure 13. Elaboration process during the classification of decay on the north façade. 


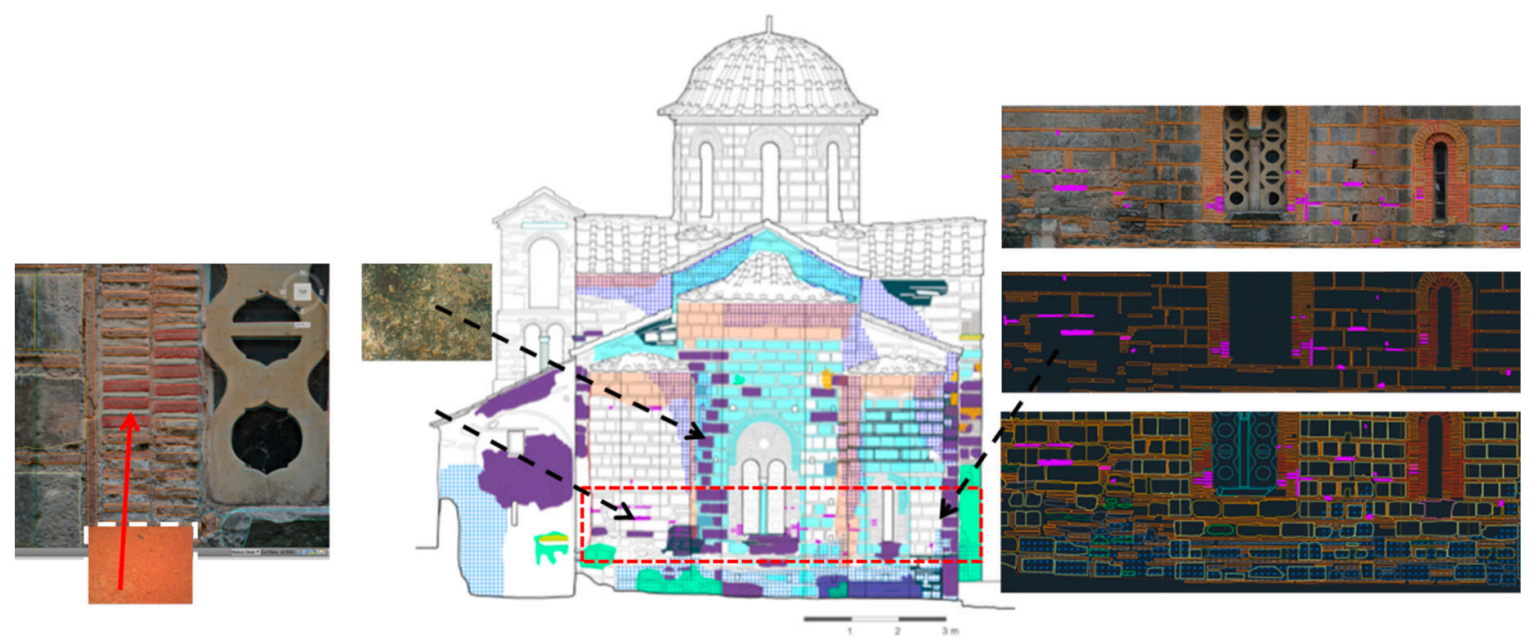

Figure 14. Elaboration process during the classification of decay on the east façade.

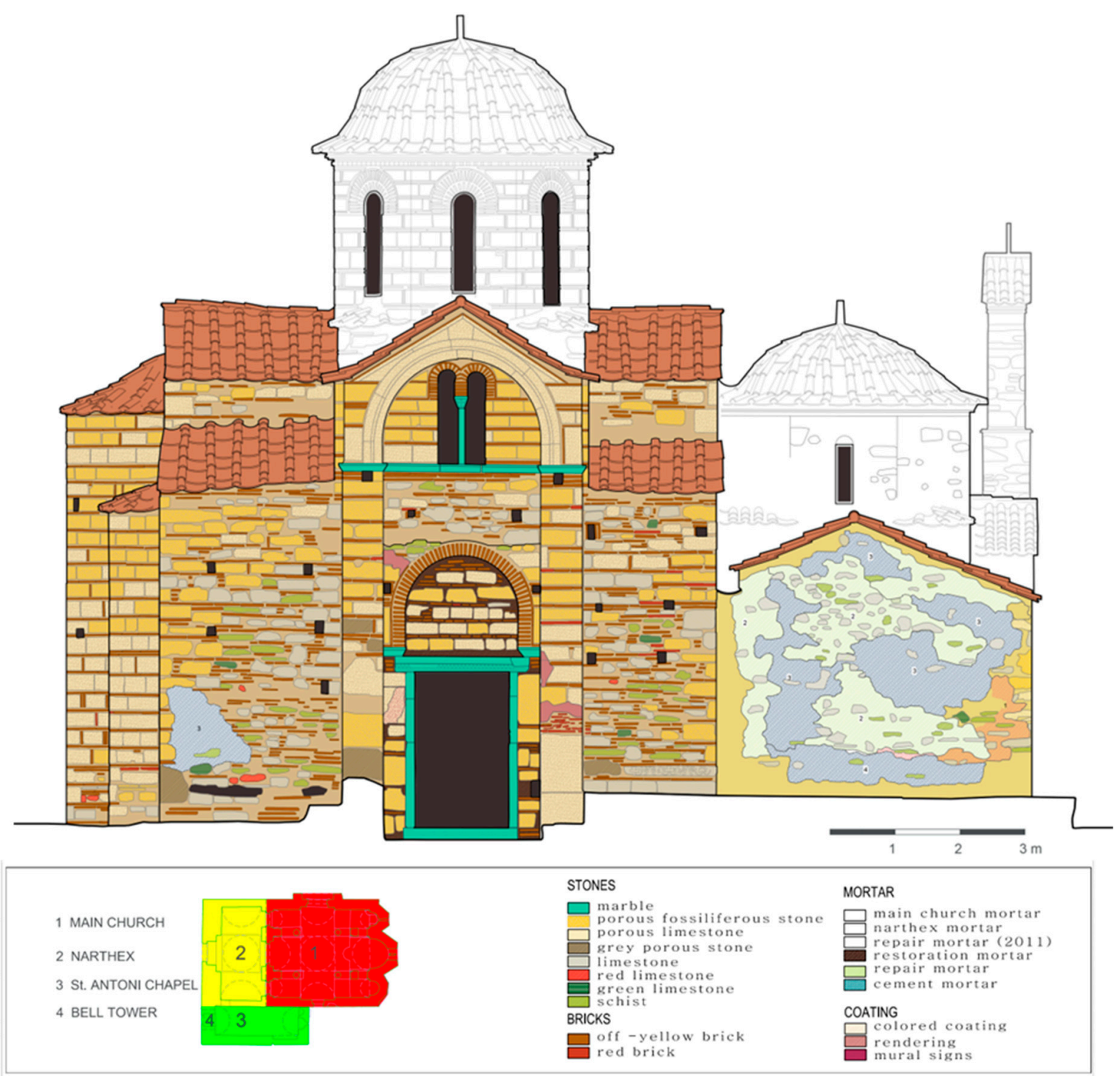

Figure 15. Thematic map of building material on the north façade. 


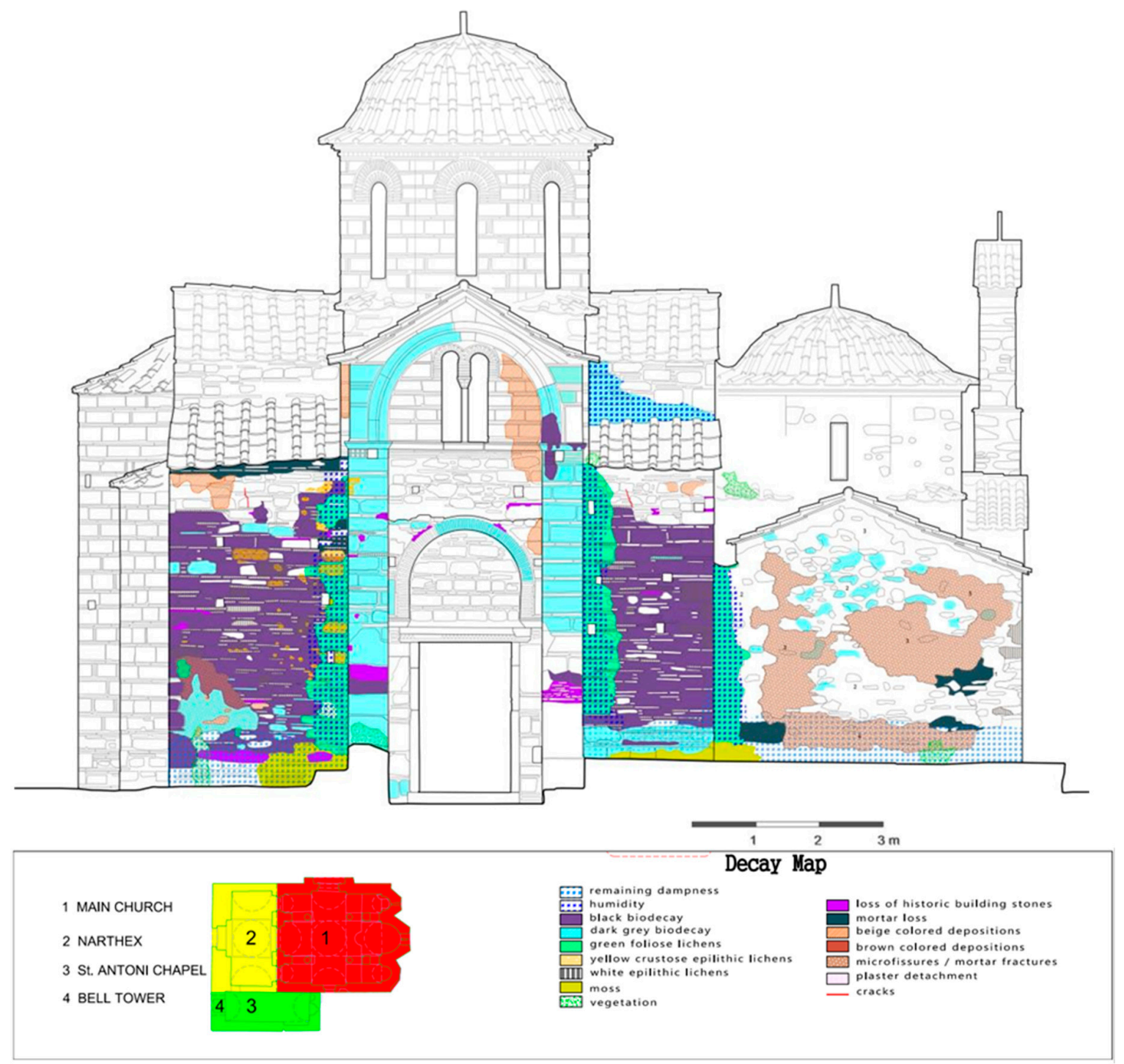

Figure 16. Thematic map of decay on the north façade.

In the elaborated thematic maps of the east façade, it is evident that its structure consists mainly of building material from the first construction phase with some restoration interventions in the lower zone of the façade (Figure 17). The main issue that should be dealt is the rising damp as well as the moisture problems in the higher zone of the façade, as illustrated in the thematic map of decay patterns (Figure 18).

\subsection{Quantitative Data Integration}

Through the multidisciplinary process, quantitative and qualitative data were produced and information regarding the preservation state of the monument was obtained. Apart from the visualization of the multidisciplinary data, quantification was possible, providing additional data for further elaboration. 


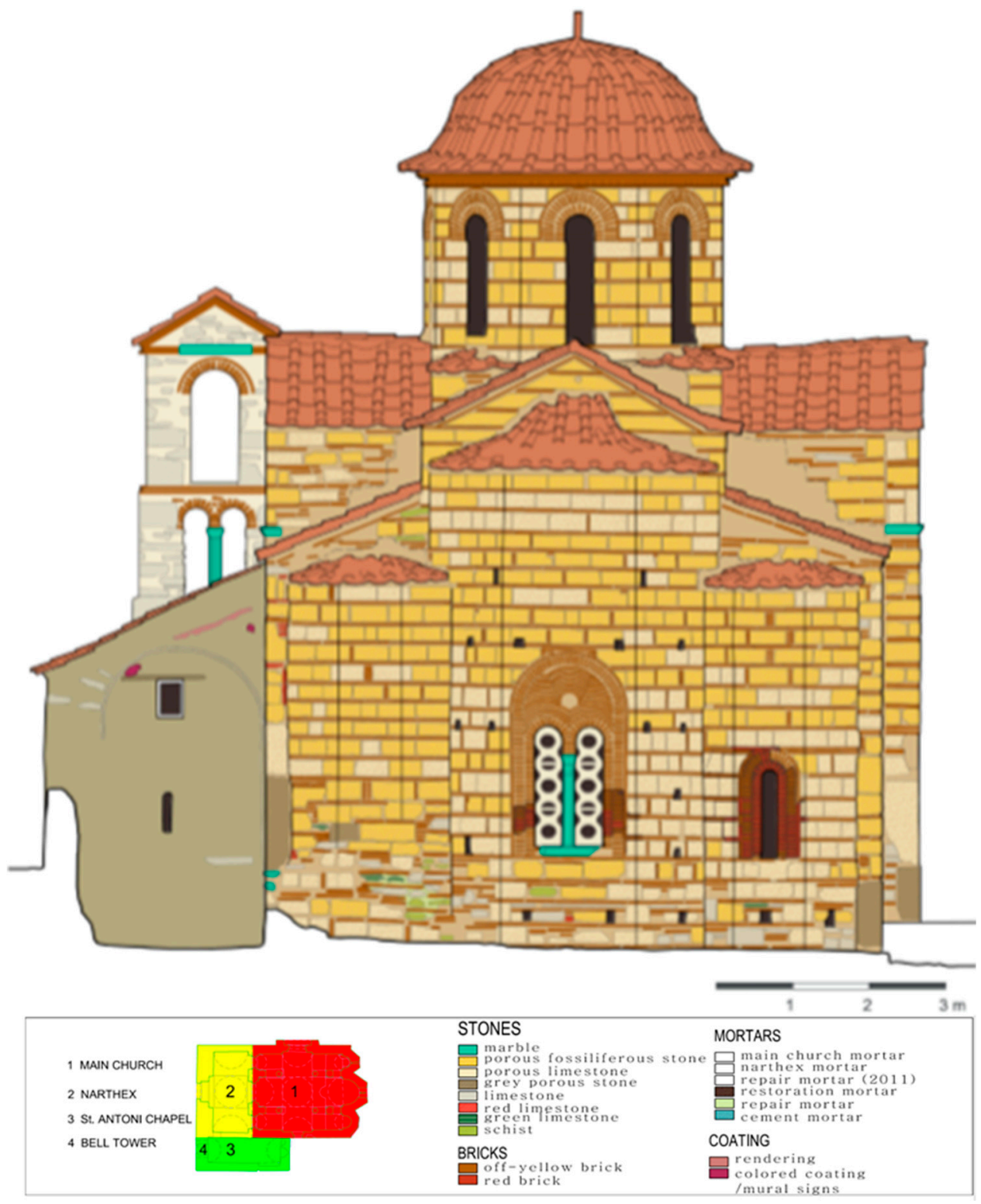

Figure 17. Thematic map of building material on the east façade.

The differences of each façade masonry type were recorded and elaborated for qualitative and quantitative investigation (Figure 19). The structural system of each façade was documented through the thematic maps, validating the architectural and historical research, their construction period and past restoration works. On the east façade, it is evident that there are a higher percentage of stone and lower ones of mortar in comparison to the other façades, depicting the strict cloisonné system that was followed for its construction. This façade has undergone very few restoration interventions and the structural system of the first construction phase is obvious.

Moreover, bio decay is one of the most deteriorating factors of the Kaisariani Catholicon. A comparative diagram was elaborated, deriving from the thematic map development to quantify and elaborate further the environmental conditions of the surroundings, which can work as a degradation mechanism for the monument (Figure 20). The north façade presents higher percentages of bio decay in comparison to the other façades, since its orientation favors bio decay growth. 

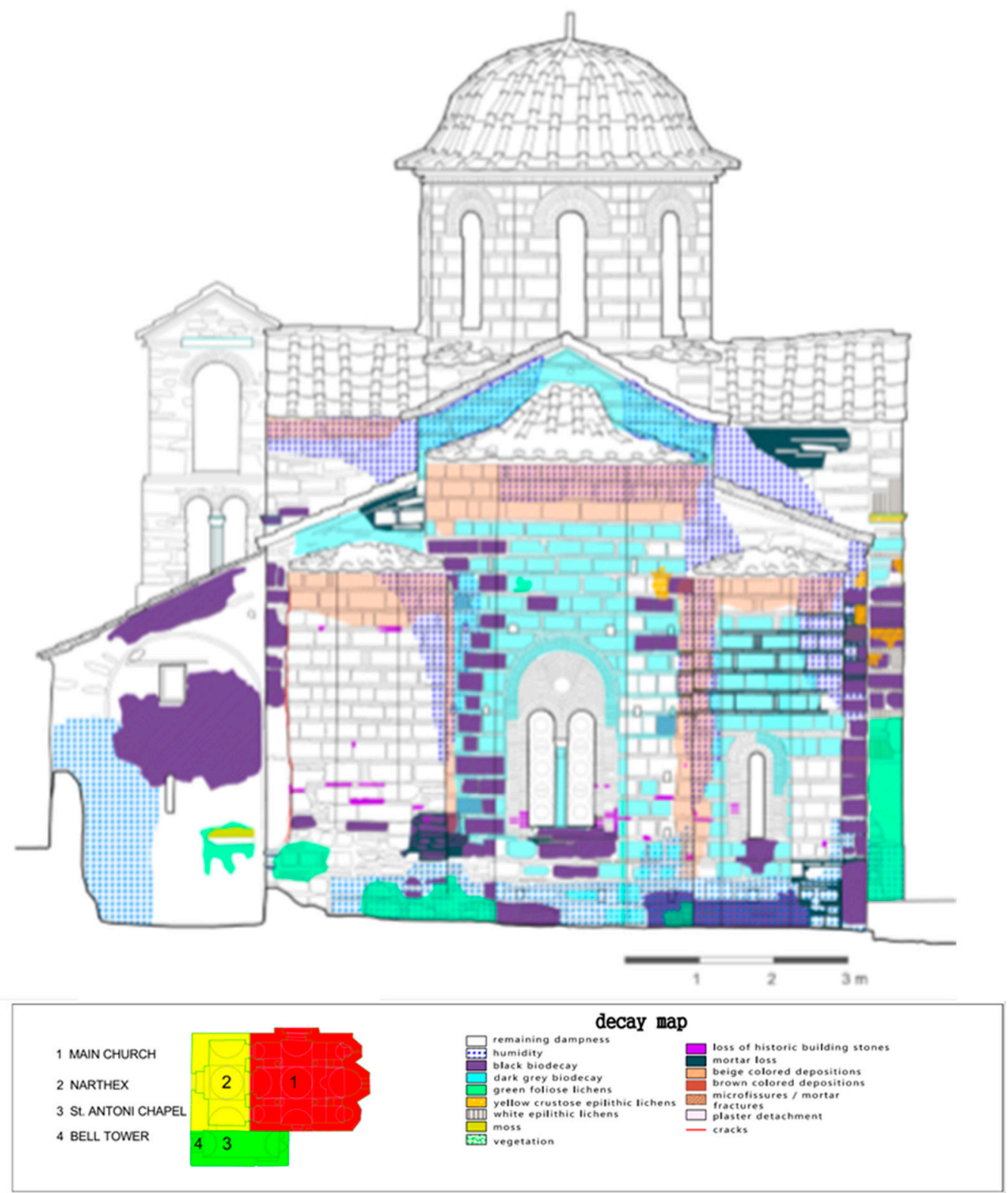

Figure 18. Thematic map of decay on the east façade.

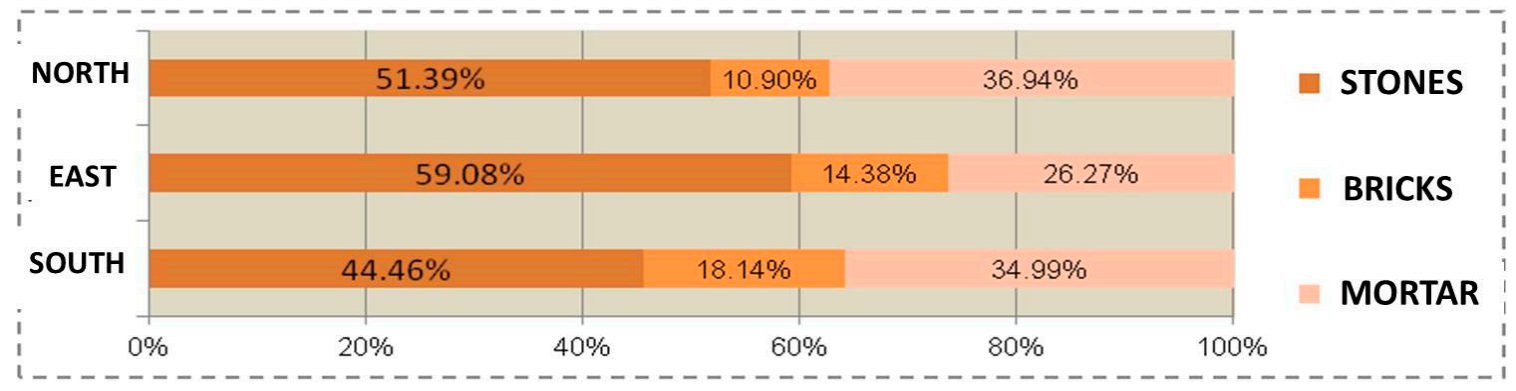

Figure 19. Diagram of the percentage of building materials in three façades of the Catholicon. 


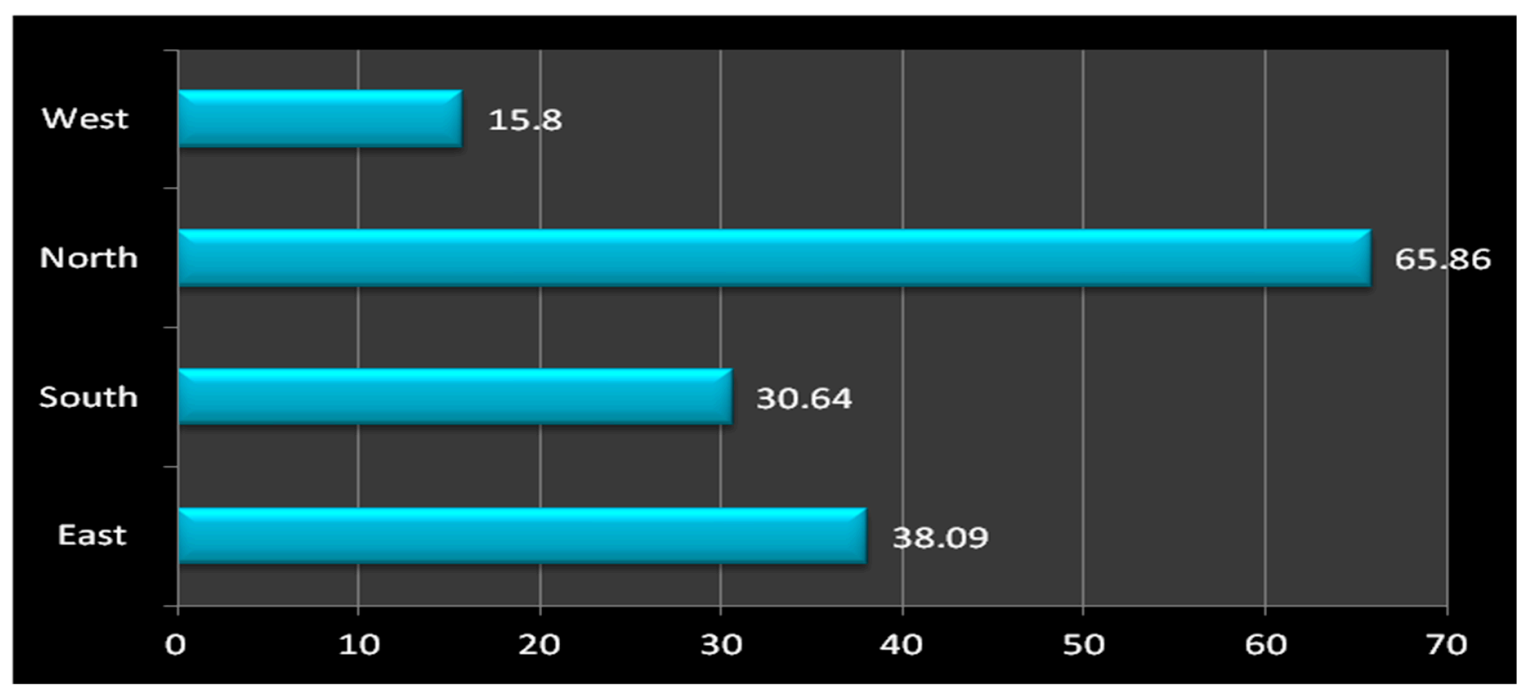

Figure 20. Diagram illustrating the percentage of bio decay on the façades of the Catholicon.

This data quantification process presents many advantages for the planning and application of conservation-restoration interventions. More accurate calculation of the amounts of the required conservation materials can be accomplished, i.e. restoration mortars, and cleaning and protection materials. Therefore, budget and cost analysis of the rehabilitation project can be organized more accurately.

\section{Conclusions}

The methodological process is the outcome of this work and is described within this paper. Within this framework, a multidisciplinary approach is presented, importing a vast amount of various data correlated and visualized within thematic maps. The four pillars of this process are the historical documentation, the architectural, the geometric and the building materials and decay documentation (Figure 21). They all contribute to the creation of multidisciplinary thematic maps and interrelate among each other.

Regarding the four basic pillars of this approach, the preservation state in terms of building materials pathology is illustrated and is in conjunction with the geometric and architectural documentation data. The past restoration works are depicted including the various construction phases of the monument (historical documentation), ensuring sustainability in terms of planning and applying of conservation and restoration interventions. Each documentation process contributes equally in the illustrated diagram for the creation of the multidisciplinary thematic maps.

Through this proposed process, it is important to follow specific steps that can lead eventually to the protection of the cultural heritage asset. The recording of the current state of preservation is among the initial and most crucial steps. In the Catholicon of Kaisariani, this was a very demanding task, since the Ministry of Culture did not give permission to perform analytical documentation processes in order to have all the relevant information, due to its high significance. Therefore, the documentation process of the historical data was crucial for the assessment of the construction phases of the monument and also document past restoration projects that were recorded. 


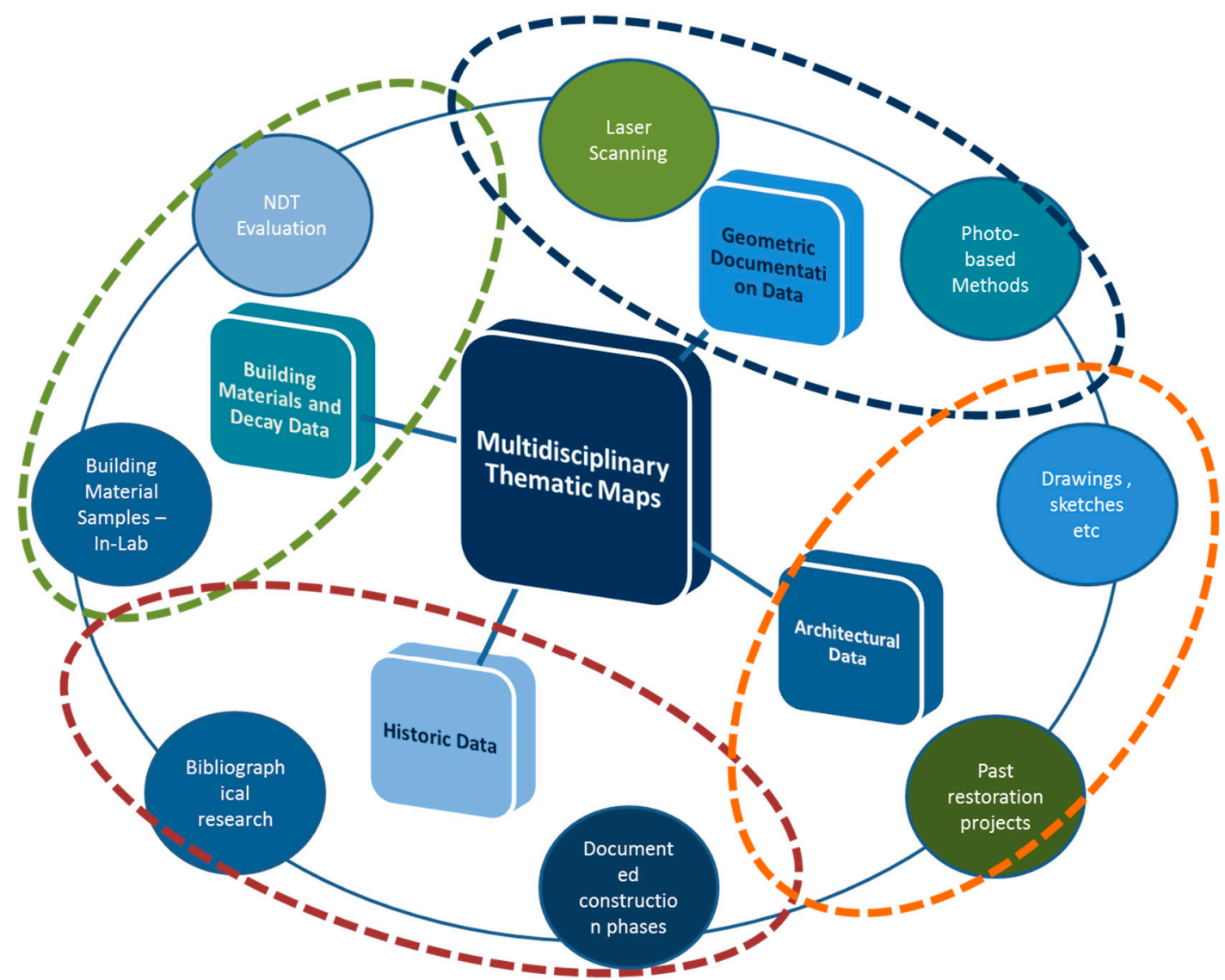

Figure 21. Diagram of the multidisciplinary process incorporating various multidisciplinary data.

In addition, the construction style of the monument aligns with the era that was built (brick and stone cloisonné masonry style). The geometric documentation provided information regarding the structural system, including building materials dimensions (width and length) in the exterior façades, as well as information regarding the structural section dimensions of the walls, validating the documented construction phases Moreover, correlation between geometric and architectural documentation depicted alterations of the monument through time, including deviation from the vertical and alteration in the structures' surface. A 10-cm deviation from vertical in the St. Antonio's Chapel is an example of deformation that can occur in the case of structures constructed in different periods, with different types of materials, etc. Information regarding the pathology of the building in terms of exterior decay factors is highlighted within thematic maps incorporating geometric, architectural and building material data investigation. The north façade presents high interest since it incorporates information of the first construction phase of the Catholicon, with the strict cloisonné system and main decay factor, the bio decay that accumulates due to environmental factors and location.

Through this investigation, the proposed processes, address various disciplines and stakeholders and utilize the thematic maps development. Through these thematic maps, whether they address the construction phases, building materials or restoration works, a correlation and management of the various disciplinary information is accomplished, contributing to the planning of interventions, if and when the need arises.

The presented processes are multidisciplinary tasks that require collaboration among architects, surveyor engineers and materials scientists/engineers (Figure 22). To conclude, the proposed methodological processes can be implemented for all cultural heritage assets to determine the preservation state and facilitate decision making for sustainable protection. In the specific case of the Catholicon of Kaisariani that was investigated for the development of the proposed process, permission was given only for the study of the exterior façades of the monument in terms of building material 
and decay characterization. Issues concerning the stratigraphy of the structure and other parts of the Catholicon such as the interior and the roof could be a next step of study whenever permission is given by the Ministry of Culture.
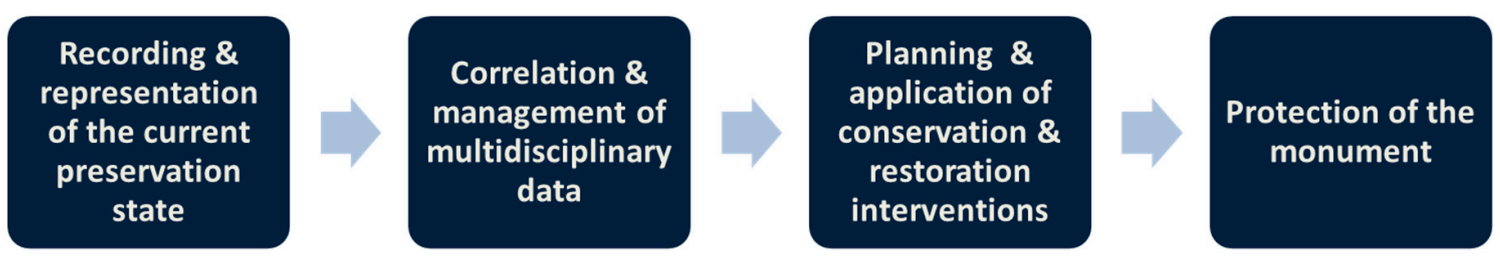

Figure 22. Diagram representing the steps toward sustainable protection of monuments.

Author Contributions: A.M., E.T.D. and E.T. conceived the research; A.M. supervised the overall writing of the paper and offered the overall methodology; G.M. performed the historical and architectural analysis; G.M. elaborated the results for her Master Thesis entitled "Planning and management of the Diagnostic Study of Material and Decay Patterns for the Katholic of Kaisariani Monastery" under the supervision of A.M. and C.I.; C.I., G.M. and E.T. analyzed the surveying data, designed the photo-based experimental data gathering, and performed the data gathering, management, elaboration and integration; E.T.D. and E.T., performed the analysis of the thematic map development; A.M., E.T.D. and E.T. conceived and designed the methodology of the study; and E.T., E.T.D. and G.M. wrote the paper. Credits for the figures that are not adopted by other reference follow the manuscript.

Funding: This research was funded by the research project "Seismic Protection of Monuments and Historic Structures-SEISMO" which is co-financed by the Greek Ministry of Education and Religions and the European Union under the action "Thales"- MIS380152, within the context of the Operational Programme-Education and Lifelong Learning, NSRF 2007-2013.

Acknowledgments: The investigation was performed within the research project "Seismic Protection of Monuments and Historic Structures-SEISMO", which is co-financed by the Greek Ministry of Education and Religions and the European Union under the action "Thales"-MIS380152 within the context of the Operational Programme-Education and Lifelong Learning, NSRF 2007-2013. In addition, the authors acknowledge the contribution of the laboratory of Photogrammetry and more specifically of Sevasti Tapinaki and Sofia Soile, for the 3D laser scanning model of the Kaisariani Monastery and advice in relevant information. The authors would like to thank M. Korre for his advice regarding the way to evaluate the deviations in the architectural documentation process. The authors would like to thank the employees of the 1st Ephorate of Byzantine Antiquities for their cooperation. This research was orally presented in its initial form at the 1st International Conference TMM_CH: Transdisciplinary Multispectral Modeling and Cooperation for the Preservation of Cultural Heritage, held during 10-13 October 2018 at the Eugenides Foundation Athens, Greece under the title "Documentation of the Building Materials and Decay Patterns of the Kaisariani Monastery" by Ekaterini T. Delegou, and has since then been modified and elaborated with further results and interpretations.

Conflicts of Interest: The funders had no role in the design of the study; in the collection, analyses, or interpretation of data; in the writing of the manuscript, or in the decision to publish the results. The authors declare no conflict of interest.

\section{References}

1. Moropoulou, A.; Delegou, E.T.; Avdelidis, N.P.; Athanasiadou, A. Integrated diagnostics using advanced in situ measuring technology. In Proceedings of the 10th International Conference on Durability of Building Materials and Components, Lyon, France, 17-20 April 2005; pp. 1116-1123.

2. Kioussi, A.; Karoglou, M.; Bakolas, A.; Moropoulou, A. Integrated Documentation Protocols Enabling Decision Making in Cultural Heritage Protection. In EuroMed 2012: Progress in Cultural Heritage Preservation; Ioannides, M., Fritsch, D., Leissner, J., Davies, R., Remondino, F., Caffo, R., Eds.; Lecture Notes in Computer Science; Springer: Berlin/Heidelberg, Germany, 2012; Volume 7616.

3. Letellier, R.; Schmid, W.; LeBlanc, F. Recording, Documentation \& Information Management for the Conservation of Heritage Places; Guiding Principles; J. Paul Getty Trust: Los Angeles, CA, USA, 2007.

4. Salonia, P.; Negri, A. Historical buildings and their decay: Data recording, analysing and transferring in an ITC environment. ISPRS Arch. 2003, 34, 302-306.

5. Meroño, J.E.; Perea, A.J.; Aguilera, M.J.; Laguna, A.M. Recognition of materials and damage on historical buildings using digital image classification. S. Afr. J. Sci. 2015, 111, 1-9. [CrossRef] 
6. Guidi, G.; Remondino, F. 3D modeling from real data. In Modeling and Simulation in Engineering; Alexandru, C., Ed.; InTech Publisher: Rijeka, Croatia, 2012; pp. 69-102, ISBN 978-953-51-0012-6. [CrossRef]

7. Kersten, T.P.; Lindstaedt, M. Image-based low-cost systems for automatic 3D recording and modelling of archaeological finds and objects. In EuroMed 2012: Progress in Cultural Heritage Preservation; Ioannides, M., Fritsch, D., Leissner, J., Davies, R., Remondino, F., Caffo, R., Eds.; LNCS; Springer: Berlin/Heidelberg, Germany, 2012; Volume 7616, pp. 1-10. [CrossRef]

8. Remondino, F. Photogrammetry-Basic Theory. In 3D Recording and Modelling in Archaeology and Cultural Heritage-Theory and Best Practices; Remondino, F., Campana, S., Eds.; Archaeopress BAR Publication Series 2598; Gordon House: Oxford, UK, 2014; pp. 63-72. ISBN 9781407312309.

9. Gabriele, G.; Danilo, G.; Marco, B. The employment of terrestrial laser scanner in cultural heritage conservation: The case study of Vallinotto Chapel in Carignano-Italy. Appl. Geomat. 2010, 2, 59-63. [CrossRef]

10. Perez Ramos, A.; Robleda Prieto, G. 3D virtualization by close range photogrammetry indoor gothic church apses. The case study of church of San Francisco in Betanzos (La Coru $\gamma^{\prime}$ a, Spain). ISPRS Int. Arch. Photogramm. Remote Sens. Spat. Inf. Sci. 2015, XL-5/W4, 201-206. [CrossRef]

11. Boehler, W.; Heinz, G.; Marbs, A. The potential of non-contact close range laser scanners for cultural heritage recording. Int. Arch. Photogramm. Remote Sens. Spat. Inf. Sci. 2010, 34, 430-436.

12. Costantino, D.; Angelini, M.G.; Baiocchi, V. Photogrammetric Approaches for the Virtual Reconstruction of Damaged Historical Remains. In AVR 2017: Augmented Reality, Virtual Reality, and Computer Graphics; De Paolis, L., Bourdot, P., Mongelli, A., Eds.; Lecture Notes in Computer Science; Springer: Cham, Switzerland, 2017; Volume 10325.

13. Doulamis, N.; Doulamis, A.; Ioannidis, C.; Klein, M.; Ioannides, M. Modelling of Static and Moving Objects: Digitizing Tangible and Intangible Cultural Heritage; Springer: Cham, Switzerland, 2017. [CrossRef]

14. Aita, D.; Barsotti, R.; Bennati, S.; Caroti, G.; Piemonte, A. 3-Dimensional Geometric survey and structural modelling of the Dome of Pisa Cathedral. In Proceedings of the International Archives of the Photogrammetry, Remote Sensing and Spatial Information Sciences, 2017 3D Virtual Reconstruction and Visualization of Complex Architectures, Nafplio, Greece, 1-3 March 2017; Volume XLII-2/W3.

15. Costantino, D.; Angelini, M.G. Qualitative and quantitative evaluation of the luminance of laser scanner radiation for the classification of materials. Int. Arch. Photogramm. Remote Sens. Spatial Inf. Sci. 2013, XL-5/W2, 207-212. [CrossRef]

16. Hess, M.R.; Petrovic, V.; Kuester, F. Interactive classification of construction materials: Feedback driven framework for annotation and analysis of 3D point clouds. In Proceedings of the 26th International CIPA Symposium, VI, WGVI/4, Ottawa, ON, Canada, 28 August-1 September 2017; pp. 343-347.

17. Costantino, D.; Angelini, M.G. Three-Dimensional Integrated Survey for Building Investigations. J. Forensic Sci. 2015, 60, 1625-1632. [CrossRef] [PubMed]

18. Adamopoulos, E.; Tsilimantou, E.; Keramidas, V.; Apostolopoulou, M.; Karoglou, M.; Tapinaki, S.; Ioannidis, C.; Georgopoulos, A.; Moropoulou, A. Multi-sensor documentation of metric and qualitative information of historic stone structures. In Proceedings of the 26th International CIPA Symposium, IV-2/W2, Ottawa, ON, Canada, 28 August-1 September 2017; pp. 1-8.

19. Moropoulou, A.; Labropoulos, K.C.; Delegou, E.T.; Karoglou, M.; Bakolas, A. Non-Destructive Techniques as a tool for the protection of Built Cultural Heritage. Constr. Build. Mater. 2013, 48, 1222-1239. [CrossRef]

20. Mourgi, G. Planning and Management of the Diagnostic Study of Material and Decay Patterns for the Katholic of Kaisariani Monastery. Master's Thesis, National Technical University of Athens, Athens, Greece, 2015.

21. Charkiolakis, N. The Monasteries of Mount Hymettus, Greece. 7 Days Kathimerini Newspaper (28 September 1997). Available online: http://www.kathimerini.gr/ (accessed on 19 April 2019).

22. Strygowsky, J. Kaisariani. Ephemeris Archaiologike. Archaiologike Hetaireia 1902, 41, 51-96. Available online: http://ww2.archetai.gr/images/pdfs/efimeris/Publ_A.E._1902.pdf (accessed on 4 September 2018).

23. Genovese, R.A. Architectural, archaeologic and environmental restoration planning methodology: Historic researches and techniques of survey aiming to conservation. Proc. CIPA 2005, 5, 295-299.

24. Moropoulou, A.; Apostolopoulou, M.; Moundoulas, P.; Karoglou, M.; Delegou, E.; Lampropoulos, K.; Gritsopoulou, M.; Bakolas, A. The combination of NDTS for the diagnostic study of historical buildings: The case study of Kaisariani Monastery. In Proceedings of the COMPDYN 2015 5th ECCOMAS Thematic Conference on Computational Methods in Structural Dynamics and Earthquake Engineering, Crete Island, Greece, 25-27 May 2015; pp. 2321-2336. 
25. Megaw, H. The chronology of some Midle Byzantine churches. Annu. Br. Sch. Athens 1934, 32, 90-130. [CrossRef]

26. Charalambos Bouras. 'Byzantine Athens: 10th-12th c. Benaki Museum 6th Supplement, Athens 2010. Available online: https://www.benaki.org/index.php?option=com_publications\&view=publication\&id= 3665\&Itemid=584\&lang=en (accessed on 19 April 2019).

27. Bouras, C.; Boura, L. Greek Religious Architecture in the 12th Century; Greece Commercial Bank of Greece: Athens, Greece, 2002.

28. Pallis, G. Topography of the Athenian Field during the Post-Byzantine Period; Post-Byzantine Monuments I: Thessalonica, Greece, 2009.

29. Delegou, E.T.; Tsilimantou, E.; Oikonomopoulou, E.; Sayas, J.; Ioannidis, C.; Moropoulou, A. Mapping of building materials and consevation interventions using GIS: The case of Sarantapicho Acropolis and Erimokastro Acropolis in Rhodes. Int. J. Herit. Digit. Era 2013, 2, 631-653. [CrossRef]

30. Pelagotti, A.; Mastio, A.D.; De Rosa, A.; Piva, A. Multispectral imaging of paintings: A way to material identification. IEEE Signal Process. Mag. 2008, 25, 27-36. [CrossRef]

(C) 2019 by the authors. Licensee MDPI, Basel, Switzerland. This article is an open access article distributed under the terms and conditions of the Creative Commons Attribution (CC BY) license (http://creativecommons.org/licenses/by/4.0/). 